\title{
A CONSTRUÇÃO DO HERÓI NO DESENHO ANIMADO: O PERÍODO DAS NARRATIVAS HÍBRIDAS (1980 - 2000)
}

\section{THE CONSTRUCTION OF HEROES IN CARTOONS: THE PERIOD OF HYBRID NARRATIVES (1980 - 2000)}

Fernando Teixeira LUIZ ${ }^{1}$

\begin{abstract}
Resumo: Revela-se, nas últimas décadas do século XX, a incidência de séries animadas protagonizadas por heróis primordiais, afinados à mitologia pagã e às Novelas de Cavalaria. Nessa direção, o presente estudo ocupa-se em rastrear, a partir de uma perspectiva crítica, descritiva e historicista, as propostas veiculadas pelo cinema gráfico entre 1980 e 2000 e suas articulações com a literatura, o cinema e os quadrinhos. Não está em cogitação, assim, a análise minuciosa de uma obra, mas o delineamento de um panorama histórico que permita visualizar as perspectivas de representação de heróis tradicionais ao longo de vinte anos. Para tanto, recorre-se à crítica especializada, às teorias da narrativa e aos estudos sobre desenho animado e indústria cultural. Em linhas gerais, a pesquisa apontou para um quadro curioso, se comparado às décadas anteriores, marcado, predominantemente, pelo hibridismo. Assim, diversos estúdios lançavam mão de uma teia de signos típicos de circuitos específicos, como o universo da mitologia, o substrato medieval, a literatura arturiana, a fantasia futurista, o faroeste norte-americano e as fontes lendárias dos samurais.
\end{abstract}

Palavras-chave: Desenho animado. Literatura. Estética. Leitor. Herói.

\begin{abstract}
The last decades of the $20^{\text {th }}$ century saw the incidence of animated series featuring primordial heroes, attuned to pagan mythology and to chivalric romance. From a critical, descriptive and historical perspective, this paper aims to track the initiatives conveyed in animated movies between 1980 and 2000 and their correlation with literature, cinema and comic books. The paper offers a historical outline, which provides an overview of perspectives that traditional heroes were represented within a twenty-year time span. In order to do so, it relies on specialized criticism, narrative theory, and on studies about animation and cultural industry. Overall, it points towards an interesting scenario if compared to earlier decades, which were mostly marked by the presence of hybridity. Thus, diverse studios employed a network of signs from specific contexts, such as mythology, medievalism, Arthurian literature, science fiction, American western, and Japanese samurai epics.
\end{abstract}

Keywords: Animated Cartoon. Literature. Aesthetics. Reader. Hero.

\section{Introdução}

O desenho animado pode ser compreendido como um campo bastante profícuo para os estudos no território da indústria cultural. Impondo-se mediante o signo visual, apresenta uma variedade de elementos típicos do discurso narrativo, como o enredo, o tempo, o espaço, a verossimilhança e, em especial, uma heterogênea galeria de personagens que povoam os universos ficcionais edificados.

Coelho (2000), atenta à produção artística direcionada à criança e ao adolescente, e enveredando por uma suposta gramática da literatura infantojuvenil, define personagem como

\footnotetext{
${ }^{1}$ Doutor em Letras. Docente da Universidade do Oeste Paulista - UNOESTE - Presidente Prudente - SP, Brasil. E-mail: fer.luiggi@hotmail.com
} 
"a transfiguração de uma realidade humana (existente no plano comum da vida ou num plano imaginário) transposta para o plano da realidade estética (ou literária)" (COELHO, 2000, p. 74). Recuperando as raízes etimológicas do termo a partir de um olhar historicista, a autora esclarece que este é proveniente do vocábulo latino persona, "nome com que os romanos designavam as máscaras usadas pelos atores gregos em suas representações teatrais” (COELHO, 2000, p. 74). Esses espetáculos "se faziam ao ar livre, em imensos anfiteatros", caracterizando-se por, a partir do disfarce, elevar a figura do ator, ampliando-lhe "a voz ou a postura" (COELHO, 2000, p. 75). Gotlib (2000), por sua vez, abordando a produção literária mediante algumas categorias estruturais, atesta que as personagens podem ser analisadas com base no papel que desempenham ao longo da diegese. A rigor, seriam catalogadas, sobretudo, em dois grandes grupos: as protagonistas e as antagonistas. As protagonistas são aquelas marcadas por aspectos superiores ao seu meio, ao passo que as antagonistas são caracterizadas pela oposição para com a figura emblemática do herói. Campbell (2007), debruçando-se sobre o acervo folclórico universal, assinala a incidência de uma pluralidade de tipos de protagonistas, que, na verdade, constituem desdobramentos do herói primordial, cabendo aqui mencionar o herói santo, o herói amante, o herói guerreiro e o herói imperador. Embora tais subclassificações sejam relevantes, enfatizamos, no território da literatura, o desempenho do herói primordial, em princípio destemido e na condição de semideus, cedendo espaço, gradativamente, a novos ciclos de protagonistas cada vez mais humanos, dotados de intrepidez e responsáveis por majestosos feitos. Nessa linha, poderíamos citar a figura de Arthur, presente nas lendas que circulavam no período de formação da Bretanha e, posteriormente, em diversos textos literários assinados por diferentes escritores.

Reverenciado na mitologia pagã, nas narrativas judaico-cristãs e nos romances de capa e espada, o herói primordial ou modelar acabou sendo, posteriormente, recuperado no cinema de animação em meio a diversas adaptações e reendereçamentos. É o herói íntegro, virtuoso, astucioso e altaneiro, protegido pelas divindades e líder nato da mais alta estirpe, desdobrandose nas imagens de Hércules, Teseu, Ulisses, Jasão, Aquiles, Édipo, Sansão, Beowulf, Percival, Belerofonte, Lancelote e outros emblemáticos soldados, mártires, cavaleiros andantes e semideuses. Constituíam homens que, designados para intrincadas missões e em meio a perigosas jornadas por terras distantes, colocavam a própria vida em risco, digladiando-se com centauros, grifos, harpias, dragões, serpentes sorrateiras, cães de três cabeças e leões assassinos.

No século XX, outros heróis, na mesma linha de Perseu, Heitor e dos cavaleiros do ciclo arturiano, conquistariam expressivo destaque. A década de 1980, dialogando com a proposta de revitalizar heróis modelares, caracterizar-se-ia por animações nitidamente realistas, fixando- 
se em séries de curta duração, tom aventuresco e apropriação de monstros do substrato medieval (bestiário) e alienígenas da ficção científica. Compreende o período de advento de desenhos como Thundarr, o barbado (1980), Caverna do dragão (1983), He-Man (1983), She-Ra (1985), Thudercats (1985), Galaxy rangers (1986) e Os Caça-fantasmas (1986). Tais desenhos, como pontua Souza (1992), recuperavam a estrutura dos contos de fadas tradicionais, sublinhando a magia, o maniqueísmo, os valores medievais e a constância de melhoramentos e degradações inscritas no itinerário do herói primordial, nítido representante de uma coletividade.

A semelhança entre essas personagens e os heróis que migravam dos cartoons na década de 1960 (Thor, Batman ou Lanterna Verde, entre outros) revelava-se, sobretudo, na construção de protagonistas solidários aos modelos de guerreiros, amantes e redentores da humanidade (CAMPBELL, 2007). Definiam-se como personagens que, reportando ao perfil do herói épico, homérico, pagão ou cristão, encontravam-se a serviço do seu grupo. Integravam, assim, valores como justiça, verdade, honra e lealdade e, na maioria das vezes, lançavam-se em enredos marcados por paixões, lutas e desavenças. Entretanto, o que diferenciava esses heróis dos grandes protagonistas da fase anterior residia no nacionalismo atenuado, ou seja, não tão exacerbado como acontecia na década de 1960. Enquanto o Super-Homem, o Homem-Aranha, a Mulher Maravilha e o Capitão América, por exemplo, insistiam na exibição de uniformes cujas cores exaltavam o estandarte dos Estados Unidos, figuras emergentes como Hank, o arqueiro, Lion, o líder dos felinos, ou He-Man, o guerreiro mais forte do universo, conseguiam compor seus ciclos independentes desses aspectos.

Paralelamente, mulheres, negros e crianças ocupavam posições secundárias, permitindo que a voz masculina predominasse em meio a obstáculos, perigos e vitórias. A maior parte das personagens femininas atuava na condição de donzelas, enquanto as imagens de afrodescendentes e de garotos assumiam postos de pouca relevância e ínfima representatividade. Surpreende ainda a ausência absoluta de protagonistas homossexuais, obesos, latinos, orientais ou de outra etnia. O que predominava nos relatos era ainda uma visão unilateral dos fatos, fundamentada no eurocentrismo, no androcentrismo e no etnocentrismo.

De 1970 a 1990, intensificou-se uma vasta produção de séries animadas que não se enquadravam, de maneira categórica, em nenhum rótulo específico. Transitavam, assim, entre a ficção científica, o universo policial, a comédia regrada, o violento western e o conto de fadas tradicional. Híbridas por excelência, as narrativas se concentravam no percurso do herói primordial, alardeando seus prodígios rumo à apoteose. Importa neste artigo, portanto, mapear o percurso desse protagonista, amparado, muitas vezes, em um projeto ideológico e em uma determinada proposta estética. Para a consecução do anunciado objetivo, a abordagem 
empregada sobre os desenhos animados foi guiada por um viés historicista, o que implica na assertiva de que as séries se encontram citadas a partir de uma perspectiva sincrônica e diacrônica do texto imagético. Não há, portanto, a pretensão de analisar exaustivamente uma obra, mas verificar os diversos modos como determinados heróis foram representados durante vinte anos (1980 - 2000). Heróis, inclusive, filiados aos perfis de Beowulf, Arthur e Tristão, e que seriam redimensionados, a partir de 2000, com Shrek e outros protagonistas que inaugurariam novos modelos de heróis na história da animação.

\section{O ciclo dos jovens guerreiros}

Segundo Campbell (2007), em todas as épocas e sob as mais diversas circunstâncias, os mitos têm inspirado, florescido e povoado a mente humana. Penetraram, ao longo da história, nas diversas manifestações culturais, reivindicando espaço na religião, na filosofia, na pintura e na literatura. Acrescentamos ao mencionado rol o cinema infantojuvenil, que, no intervalo que permeia o final da década de 1960 e princípio dos anos 1980, fascinava crianças e adolescentes com heróis lendários que arriscavam a própria vida para salvar seu povo de quimeras, minotauros, górgonas e hidras. Era o momento de Hollywood investir em títulos como Jasão e os argonautas (1968), As novas viagens de Simbad (1974), Fúria de titãs (1981) e Conan, o destruidor (1982). Paralelamente, o êxito de bilheterias conquistado pela alta tecnologia de Guerra nas estrelas (1977) e a proposta arrebatadora Blade runner, o caçador de androides (1982), evidenciavam uma nova tendência no mercado cinematográfico de animação: narrativas que oscilavam entre a estética futurista, caudatária de Space Ghost (1966) e Os Herculóides (1966), e o substrato medieval, em sintonia com o universo de bruxas, dragões e cavaleiros revisitados por filmes de aventura e pelos contos de fadas da Disney.

A estética futurista pode ser detectada na presença de uma cadeia sígnica que se repetia, de modo sistemático, em diversas produções do gênero. Abrangia a incidência tautológica de naves espaciais, robôs com vida própria, armamento a laser e alienígenas na condição de adversários ou coadjuvantes. O substrato medieval, por sua vez, abusava de ícones circunscritos à cultura da Idade Média, concentrada em mosteiros, vilarejos e palácios, e alimentada por feiticeiros, magos, duendes, gnomos, ogros e demônios. Ademais, recorria-se também a elementos como espadas, talismãs e cetros encantados. Coelho (1989), debruçando-se sobre os contos de fadas tradicionais, chama a atenção para algumas peculiaridades igualmente respaldadas no mundo feudal, como a constância de metamorfoses, o poder das profecias, a reiteração dos números três e sete, a intervenção sobrenatural, a autoridade nas mãos de anciões 
e, na maioria das vezes, a resignação feminina. No amálgama entre o futurismo sombrio e a tradição gótica, vicejava o herói modelar, fiel às raízes greco-latinas e consciente de seu dever diante do grupo social que representava. O herói grego, para Jaeger (1986), não temia as situações de risco e tampouco demonstrava apego aos bens materiais. Por pertencer a uma linhagem notável, possuía virtudes essenciais, como a valentia, a fidelidade e a honra. Realçavase ainda o fato de ser astuto, vigoroso, sábio e viril, capaz de comandar multidões em impressionantes conquistas. Seu comportamento, característico do mito homérico, atravessaria todo o período medieval, propagando-se nos ideais, de natureza cristã, difundidos pelo ciclo bretão arturiano e, por conseguinte, incursionados pelo mito dos nobres cavaleiros.

Para Souza (1992), a fusão entre a ficção científica e o misticismo do século XIV tornava-se patente na vertente do desenho animado dos anos de 1980, uma vez que misturava ambientes palacianos a máquinas que refletiam as projeções da época a respeito do segundo milênio. Na realidade, constituía uma fórmula centrada em enredos bastante previsíveis, que se ajustavam, em larga escala, às expectativas, anseios e preconceitos do leitor. A primeira animação projetada nesse campo foi O poderoso Mighton (1967), dos estúdios Hanna-Barbera. Ambientando a narrativa em um cenário pré-histórico, apresentava-se a saga do jovem Tor, imerso em uma atmosfera selvagem, tétrica e perigosa. O diferencial de Tor estava em sua clava mágica, que, em momentos de tensão, era erguida e o transformava no guerreiro Mighton. Tog, seu dinossauro de estimação, igualmente ganhava poderes extraordinários, convertendo-se em um dragão imponente e implacável. A animação dialogava verticalmente com o herói da Marvel - Thor -, tendo em vista que o protagonista possuía o mesmo nome do deus nórdico, o capacete córneo semelhante ao utilizado pelos vikings e a clava como alusão ao martelo do folclore escandinavo. A máscara explicitava uma relação dialógica com Space Ghost e Batman, já reconhecidos na ocasião e com visual bastante similar. No fluxo de animações de 1960, $O$ poderoso Mighton erigia o enredo em um passado distante, indeterminado, mítico, povoado por criaturas pré-históricas e, simultaneamente, monstros apocalípticos.

Em 1980, Thundarr, o bárbaro, da Euby Spears, emplacaria uma proposta não muito diferente, lançando mão do elemento futurista e apocalíptico à moda de $\operatorname{Mad}_{\operatorname{Max}}^{2}$ (1979). Se O poderoso Mighton concentrava a ação em uma pré-história mítica, Thundarr, o bárbaro explorava um futuro distante, catastrófico e enigmático. Thundarr era um guerreiro que, munido de uma espada de energia, empenhava-se em salvar a humanidade de monstros, mercenário e entidades soturnas. Para tanto, contava com a jovem Ariel, dotada de poderes

\footnotetext{
${ }^{2} \mathrm{O}$ filme de George Miller apresenta uma Austrália distópica, deteriorada, formada por uma sociedade brutal, decadente e desintegrada.
} 
sobrenaturais, e Ukla, uma fera semelhante ao Chewbacca de Guerra nas estrelas. As referências intertextuais às produções culturais da época eram múltiplas. Do citado Guerra nas estrelas, ressaltava-se o sabre de luz utilizado pelo protagonista em sangrentas batalhas. De Mad Max, observava-se a representação futurista do planeta Terra enquanto espaço desolado e deprimente. Dos quadrinhos de Conan, acentuava-se a performance errante do herói, solidário à condição de bárbaro. Das lendas, apropriava-se de bruxos e lobisomens. Da mitologia, fazia alusão aos ciclopes e a Argos Panoptes, o colosso de mil olhos. Do filme O planeta dos macacos (1969), intercalava o vale de homens símios.

Três anos depois, estrearia a série que mesclaria elementos de $O$ poderoso Mighton a Thundarr, o bárbaro. Do primeiro título, incorporaria todo o ritual latente na metamorfose que transformaria Tor em Mightor. Do segundo título, faria uso do visual da protagonista - corte de cabelo e vestimentas - bem como da espada mágica, da presença de gênios protetores e de signos da ficção científica. Tratava-se da animação He-Man e os mestres do universo (1983), um dos maiores sucessos do mercado norte-americano e da história da Filmation (MORELLI, 2010). Do mesmo modo que os protagonistas Super-Homem, Batman e Homem-Aranha, o nobre He-Man também possuía dupla identidade, exibindo-se ora na pele do reservado príncipe Adam, ora como o homem mais forte das galáxias. Em posição análoga aos heróis dos quadrinhos e da mitologia, ele estava sempre a serviço de sua comunidade, caracterizada aqui como a população do reino de Etérnia. Além disso, sua missão era também a de proteger o misterioso Castelo de Grayskull, cujos poderes obscuros incitavam a cobiça do antagonista Esqueleto. A série envolvia criaturas que reportavam ao imaginário medieval, abarrotado de duendes, bestas e objetos mágicos, impressos na construção de uma galeria criativa de vilões, como Maligna, Aquático e o Homem-Fera. Recorria igualmente às figuras da mitologia grega, cabendo aqui citar as personagens Tríclope, em referência aos gigantes de um olho só, e Teela, cujos traços e agilidade reportavam às amazonas. Na mesma proporção, acrescentavam aspectos futuristas ao enredo, identificados no maquinário desenvolvido pelo sábio Mentor e na construção visual do antagonista Mandíbula, criatura híbrida que carregava expressão humana e traços de um androide.

O rentável sucesso de $\mathrm{He}$-Man e dos demais defensores do universo possibilitou com que fosse engendrada, dois anos depois, sua irmã gêmea $S h e-R a$. A fórmula administrada era basicamente a mesma. Mesclando, mais uma vez, a atmosfera futurista associada a signos medievais, promovia-se uma heroína que lutava para libertar seu mundo da ameaça representada pelo inimigo Hordak. Nessa linha, o espaço palaciano de Etérnia, de He-Man, era substituído por Ethérea, pouco alterando do mundo de superstições e vassalagem. O duende 
Gorpo, responsável pela comicidade, cedia a tribuna para o Corujito. O antagonista Esqueleto era recriado na imagem de Hordak, que, inclusive, preservava em seu figurino uma coroa de ossos em referência ao vilão que o antecedia. A sequência de transformação de Adora em She$R a$, tendo como fundo o Castelo de Grayskull, era similar à que convertia Adam no homem mais forte do universo. O fundo moralizante, explícito no desfecho de cada episódio, mantinhase, do mesmo modo que se preservavam as nuances maniqueístas. Talvez a contribuição que tenha representado o desenho She-Ra esteja, basicamente, na projeção da primeira série do período (1980 - 2000) protagonizada por uma figura feminina, em pleno diálogo com a imagem emblemática da Mulher Maravilha, da DC Comics, expressiva em décadas anteriores.

Conscientes do filão de mercado que representava a epopeia dos desenhos em questão, novos estúdios passaram a investir em produções partidárias da mesma estrutura, como apontavam Caverna do dragão (1983), Thundarcats (1985) e Visionários (1987).

Caverna do dragão ${ }^{3}$, da Marvel, abordava o cotidiano de cinco adolescentes - Hank, Sheila, Diana, Presto e Erik - e uma criança - Bobby - em um cenário salpicado de tons sombrios e referências a uma infinidade de mitologias. Como aliado, contavam com o misterioso Mestre dos Magos. Como adversário, deveriam enfrentar não apenas o satânico Vingador, mas também um gigantesco dragão de cinco cabeças, andrógino, chamado Tiamat, em referência intertextual à divindade da Babilônia, descrita, no mito, como uma serpente. Do mesmo modo que ocorria com os heróis da Antiguidade, era necessário que os jovens se submetessem a uma miríade de provações (como Hércules e seus doze trabalhos) antes de regressar ao lar. As sequências de cenas, na verdade, constituíam uma encruzilhada intertextual em que desfilavam os unicórnios das crenças populares, as bestas apocalípticas e os guerreiros medievais.

Thundercats, em contrapartida, faria uso do misticismo e, ao mesmo tempo, da alta tecnologia. Um grupo de humanoides felinos formado por Lion, Tygra, Panthro, Cheetara, Willy Kit e Willy Kat, bem como o mascote Snarf, aterrissavam em um planeta distante denominado Terceiro Mundo. Entre perigos e ameaças, lutavam para sobreviver em meio a desavenças com inimigos mutantes e com uma múmia incognoscível que assumia a forma de Mumm-Ra, entidade supostamente egípcia, dotada de exacerbada força. Nessa animação, os estúdios Rankin/ Bass apropriaram-se, mediante a intertextualidade, de fórmulas já aplicadas em outros desenhos, como o uso da espada mágica (Mestres do universo), a projeção, no céu,

\footnotetext{
${ }^{3}$ Série baseada em um famoso jogo de RPG. Com o tempo, outras personagens também migrariam dos games para a TV, como ocorreu nos casos de Pac Man (1984) e dos episódios configurados na marca Super Mário Brothers (1989).
} 
de um feixe de luz com a logomarca do grupo (tal qual acontece na ficção protagonizada por Batman) e o fato de as personagens transitarem em um mundo desolado, enigmático, destruído e que, no passado, tratava-se possivelmente do próprio planeta Terra (temática distópica já revisitada por Thundarr, o bárbaro).

Visionários, os cavaleiros da luz mágica, dos estúdios Sumbow e TMS, seguiam uma trilha similar. Na linha das Novelas de Cavalaria, ilustravam o percurso de guerreiros que poderiam se transformar em animais, vivendo longos embates e torneios com o grupo rival. A tecnologia, aqui, tinha efeito atenuado, priorizando a magia a partir da releitura futurista do ciclo bretão. Um dos protagonistas, inclusive, carregava o nome de Mago Merklyn, em alusão a Merlin. A série Visionários, porém, não rendeu aos estúdios produtores saldos positivos em proporção análoga a Thundercats e Caverna do dragão. Uma explicação plausível para tanto poderia ser encontrada no desgaste da fórmula empregada através dos anos, que já não proporcionava ao público nenhuma novidade. No entanto, com As tartarugas ninja, também de 1987, observa-se como a mesma fórmula poderia ser reinventada, ainda que oferecesse ao destinatário o já dito, o já codificado, o já reiterado. A partir de agora, a tradição milenar dos samurais seria revisitada, no cenário de Manhattan, mediante a ação de novos protagonistas. Em profícuo diálogo com A tartaruga Touchê, de 1962, o desenho se concentrava nas aventuras dos quatro répteis com nomes de artífices renascentistas - Donatelo, Raphael, Leonardo e Michelangelo. Na condição de heróis épicos, encarregavam-se de proteger a cidade de antagonistas de outra dimensão. A fantasia medieval, comum nas outras séries, era substituída pelo universo das artes marciais, ao passo que a ficção científica permanecia diluída por toda a diegese. Ademais, predominava uma proposta ainda mais tradicional na série, uma vez que era a voz masculina que prevalecia abertamente na narrativa, reservando às figuras femininas (e em especial à jovem jornalista April O’Neil) a condição passiva de donzelas.

Na esteira d'As tartarugas Ninja, ecoavam os episódios de Dinosaucers (1987). O desenho era protagonizado por dinossauros evoluídos, que pilotavam espaçonaves e manipulavam armamentos da mais alta tecnologia. Novamente ao sabor da ficção científica, a série em questão apontava para um novo painel que se plasmava na década de 1980, em que mutantes, felinos e outras formas inusitadas, diferentes, heterogêneas, assumiam o posto de heróis primordiais. Heróis, não obstante, enraizados nos modelos de Homero, da literatura arturiana e do poema épico anglo-saxão Beowulf e, por conseguinte, no arquétipo de pais, protetores, provedores, responsáveis pela ordem e militantes na luta contra as forças do caos. 
Nas trilhas de uma tendência cada vez mais inclusiva e futurista, $X-M_{e}^{4}$ (1992), adaptado dos quadrinhos da Marvel, apostava em heróis também exóticos, aviltados pela sociedade e, como as tartarugas e os dinossauros, perseguidos em razão da excentricidade que ostentavam. A fórmula, outrora repetitiva, reinventava-se mais uma vez, engendrando heróis não tão inabaláveis, mas com crises de identidade e, muitas vezes, hostilizados pelo governo e vítimas da intolerância do meio. Tal dado, ainda que não atenuasse o maniqueísmo, tornava a narrativa mais convincente. Possivelmente a saga de Wolverine e dos demais guerreiros formados pelo professor Xavier tenha como ancestral não a astúcia de Ulisses ou o temperamento de Hércules, mas o pioneirismo moderado do herói grego Eneias, que se despia da coragem elevada dos demais guerreiros épicos e se declarava desolado e à procura de si mesmo. Virgílio, ao relatar sua história, traçava o percurso de um troiano que, fugindo da destruição da própria cidade, embarcava com a família mar adentro em busca de um lugar onde pudesse se firmar e fundar um novo povoado. Sua virtude residia não apenas na meta pelo reconhecimento como respeitado mártir, mas pelo bem coletivo. Entre mil peripécias, não hesitava em demonstrar a fragilidade, a insegurança e as fraquezas, evocando o amparo de Júpiter quando necessário. Dialogando com tal perfil, Wolverine entremostrava seus ressentimentos e expressava abertamente seu amor pela jovem Tempestade, bem como o medo de perdê-la - questão jamais cogitada entre os heróis que o precediam.

Provavelmente um dos mais impressionantes títulos desse período ainda seja Akira (1988), obra-prima de Katsuhio Otomo. A história era orientada por uma proposta bastante alternativa aos padrões eurocêntricos e etnocêntricos da época. Utilizando tomadas majestosas, movimentos realistas e protagonistas bastante jovens (Kameda e sua gangue) em ágeis motocicletas que deixavam rastros de luz, a narrativa exibia uma Tóquio semelhante à Detroit de Robocop. No desenho, a capital japonesa era reconstruída após um cataclismo em 16 de julho de 1988. Atento a essa perspectiva apocalíptica, Denis (2010) salienta que o longametragem erigia-se como uma reflexão em torno do poder de destruição nuclear, em estreita relação com a tragédia de Hiroshima e Nagasaki ocorrida em agosto de 1945. Para os japoneses, a bomba e suas consequências estavam, desde então, presentes no imaginário popular. A rigor, a aceitação mundial do anime revelava não apenas o sucesso do filme, mas também a gradativa ascensão das representações nipônicas, livres da estética norte-americana. Assim, ao contrário de Thundarr, o bárbaro e Mad Max, a cidade após a destruição nuclear não se encontrava esfacelada, em ruínas. A Nova Tóquio destacava-se pelos gigantescos edifícios e maquinário

\footnotetext{
${ }^{4}$ X-Men tornou-se uma marca da Marvel para designar um grupo de heróis veiculados em quadrinhos, filmes e desenhos animados.
} 
de última geração, projetando uma metrópole monumental, futurista e, ao mesmo tempo, violenta e perigosa.

Além do material citado, as séries do final do século XX apostariam em outras fusões enfeixadas sob prisma híbrido, multiforme e atento às novas exigências do mercado, conforme discorreremos adiante.

\section{O ciclo dos cowboys, xerifes e justiceiros}

Antes de dar início à presente problematização, convém uma apreciação introdutória sobre a categoria cinematográfica rotulada popularmente como bang-bang. Aumont e Marie (2003), atendo-se à definição do gênero, apontam a dificuldade de limitá-lo unicamente a ficções que se desenvolveram no período que se estende da Guerra de Secessão ao desaparecimento da Fronteira $(1865$ - 1890). A justificativa para tanto estaria no fato de que existem inúmeros faroestes modernos, como também produções, protagonizadas por cowboys, que se voltam a outras temáticas, como, por exemplo, a luta pela independência contra os ingleses. Aumont e Marie (2003) ainda informam que, para efeitos didáticos, foi proposto agrupar as narrativas do oeste norte-americano em alguns ciclos, como os de povoamento, das guerras indígenas e do conflito méxico-texano, entre outros.

Nas séries animadas, observa-se como tal gênero foi empregado e renovado mediante uma perspectiva futurista mesclada ao realismo mágico. Cavalcanti (1975) assinala que o futurismo, como expressão artística, valorizava o dinamismo, as máquinas, os motores e o novo sentimento que o progresso conferia à vida e ao cotidiano do homem. Quanto ao realismo mágico, conceitua-se, conforme aponta Coelho (2000), como a fusão entre realidade e fantasia, em que elementos excêntricos e fantásticos são incorporados ao dia a dia com certa naturalidade e regularidade.

Os desenhos em debate interagiam, basicamente, com três mitos do Velho Oeste: o justiceiro, o cowboy e o xerife. O primeiro, ainda que seja alvo da alcunha de fora-da-lei, empenhava-se em garantir que a ordem fosse instituída, haja vista o abuso de poder por parte da elite e a ineficiência do sistema de segurança do município. Abrangia heróis próximos aos

perfis de Batman, Homem-Aranha e, sobretudo, Robin Hood. O segundo se destacaria pelo aspecto aventureiro, cínico e galanteador, representado na sétima arte nas personagens interpretadas pelo ator Tom Mix. O terceiro, nessa direção, integrava a milícia local, responsabilizando-se pelo zelo e bem-estar da comunidade, conforme sugeriam os delegados 
Curly Wilcox [No tempo das diligências (1939)], Will Kane [Matar ou morrer (1952)] ou Rooster Coagbum [Bravura indômita (1969)].

O Cavaleiro solitário e o destemido Zorro estavam entre os justiceiros mais revisitados pela indústria cultural. John Reid, o citado cavaleiro, acompanhado do índio Tonto, protagonizou sua primeira animação em 1966 pela Format Film, reaparecendo, pela Filmation, em 1980. Zorro, porém, beneficiava-se de uma composição que estabelecia estreitas relações não apenas com o gênero cinematográfico do faroeste, mas também com a literatura de capa e espada, em posição paralela aos romances de Alexandre Dumas. Na série de 1981, da Filmation, exaltava-se a atuação do protagonista mascarado contra os desmandos do Capitão Ramon sobre a população oprimida. A meta do estúdio era preservar a longa trajetória da personagem, que, astuciosa e de expressivo carisma, migrava dos quadrinhos para o cinema e, mais tarde, para o desenho animado. Ambientada no século XIX, a série sublinhava a resistência de um homem frente ao autoritarismo do exército espanhol. Além disso, é prudente salientar que a retórica futurista, que ganhava força após o apogeu de Guerra nas estrelas (1977), não estava, nas aventuras de Zorro, em evidência. Ainda que a saga de Luke Skywalker igualmente se valesse da luta de grupos marginais contra a arbitrariedade do Império, a animação do espadachim mascarado optou por preservar as aventuras de Don Diego de La Vega conforme a atmosfera original dos quadrinhos. A Filmation evitava, portanto, introduzir elementos de ficção científica no grande clássico.

A inserção do mundo country - com signos típicos do oeste norte-americano (botas, esporas, fivelas, pistolas etc. - aos moldes da linguagem futurista teve como precursor os episódios de Galaxy rangers (1986), desenho contemporâneo ao sucesso de Mestres do universo (1983), Caverna do dragão (1983) e Thundercats (1985). Projetado pelos estúdios Gaylard Productions e TMS Entertainment, a ficção se debruçava sobre os conflitos vivenciados por quatro agentes - Doc, Nico, Shane e Zachary - comprometidos em combater a criminalidade no espaço sideral. O uniforme dos heróis estabelecia o diálogo metagenérico com os códigos estéticos do gênero faroeste e da ficção científica, já que, de um lado, exibiam chapéus de couro, lenços no pescoço, longas botas e broches dourados de cinco pontas, e, de outro, portavam pistolas a laser e cavalgavam em androides com formas de cavalos de metal. Paralelamente, a narrativa acrescentava parceiros alienígenas e demoradas sequências em majestosas espaçonaves, que lembravam o tom épico de Jornada nas estrelas (1979). A fórmula, outrora estabilizada tanto em Zorro quanto em Cavaleiro solitário, mostrava-se renovada a fim de atender a um novo público que se curvava diante de séries cada vez mais híbridas, alternativas e sofisticadas. 
Ainda que Galaxy rangers consolidasse a atmosfera futurista, determinados estereótipos, típicos dos faroestes tradicionais, não foram abandonados no desenho animado. Os heróis ainda obedeciam aos modelos idealizados dos conquistadores europeus, supostamente letrados e civilizados. O índio, apresentado na condição de aborígene ou sujeito inculto, acabava presidindo a condição de coadjuvante. Exemplo disso pode ser detectado em Tonto, leal parceiro do Cavaleiro Solitário, e com pouco destaque ao longo dos episódios. Nas adaptações futuristas do Velho Oeste, o índio era substituído pelos extraterrestres, sujeitos que, exóticos e diferentes por natureza, sempre assumiam posição subalterna ou papel de antagonista.

Talvez a série Bravestarr, de 1987, conseguisse fugir um pouco à regra ao propor um homem pardo, com traços indígenas, na pele de protagonista. Diferente de Galaxy rangers, que ambientava os episódios no século XXI, Bravestarr focava um futuro ainda mais distante: o século XXIII. A ação aqui transcorria no planeta Texas, local onde o xerife Marshal Bravesstarr protegia sua comarca de inescrupulosos adversários, reproduzindo, mais uma vez, a estrutura maniqueísta comum a outras produções do gênero e do período. O diferencial do mencionado desenho estaria, entre outros aspectos, no cavalo ciborgue, que, antropomorfizado, acompanhava o herói em suas andanças e se comportava como seu fiel escudeiro. Ademais, o xerife possuía poderes incomuns: a força do urso, a velocidade do puma, os olhos do falcão e os ouvidos do lobo. Com a seleção sígnica de animais do oeste norte-americano, extraindo características peculiares a cada um deles - força, velocidade, visão e audição aguçadas edificava-se, nas malhas do texto, a indicialidade (SANTAELLA, 1983) com o propósito de recuperar e acentuar as relações com seus ancestrais indígenas. Por outro lado, pretendia também delinear e descrever, por meio da metáfora, a equivalência entre o homem e as forças da natureza. O resultado seria a composição de um cidadão imbuído de valentia, destreza e perfeição, tal qual a plêiade de heróis gregos, centuriões e semideuses. É como se os estúdios almejassem estabelecer a fusão entre duas personagens emblemáticas - He-Man e o Cavaleiro solitário - conferindo poderes extraordinários a um cowboy - aspecto, até então, inédito.

O desgaste da fórmula, infelizmente, acabou interferindo, de maneira negativa, na recepção dos episódios. Prova disso é que, de acordo com Morelli (2010), o êxito mediano de audiência contribuiu para que Bravestarr fosse o último trabalho da Filmation e, por conseguinte, encerrasse o ciclo de vaqueiros, xerifes e vingadores lendários. 


\section{O ciclo dos heróis do cinema}

A década de 1960 testemunhou, em larga escala, a adaptação de personagens das páginas em quadrinhos para o competitivo território da animação. Tributários de Superman, que em 1941 migrou de uma mídia para outra, acentuou-se, a partir de 1966, o investimento em ícones reverenciados pela cultura pop daquele contexto, como Thor, Hulk, Capitão América e, mais tarde, Batman, Lanterna Verde, Mulher Maravilha e Homem-Aranha. A década de 1980, por sua vez, vislumbrou um processo inédito, em que heróis transitavam não dos cartoons, mas do cinema e dos seriados matinais para o desenho animado.

Nesse processo, há nítida simplificação na construção do roteiro e, em especial, na definição do plot. Exibidos para um público infantil, as personagens que transitavam de uma mídia para outra, perdiam a partir de então, alguns dos principais aspectos que as caracterizavam nos grandes sucessos de bilheteria da época. A meta dos estúdios de animação era adequar os heróis às expectativas da criança e à nova linguagem dos desenhos. É o que pode ver visualizado nas adaptações de Os três patetas (1934), Rambo (1982), Os caça-fantasmas (1984), Robocop (1987) e O Máscara (1994). A rigor, a violência e a construção do humor acabavam recebendo um novo tratamento nas aventuras que ocupavam a programação televisiva daquele período.

Assim, apesar de ser um fenômeno da penúltima década do século XX, o prelúdio dessa empreitada pode ser apurado em Robobos, de 1978, oferecendo uma leitura futurista do grupo que se popularizou nos meios de comunicação, a partir de 1934, como Os três patetas. Na curiosa produção da equipe Hanna-Barbera, o trio composto por Larry, Moe e Curly se transformava em um conjunto de heróis cibernéticos, com articulações que se alongavam e possibilitavam movimentos cada vez mais ousados e sofisticados. Dado o caráter humorístico da animação, os protagonistas não agregavam traços superiores ao seu grupo, como os guerreiros primordiais de ascendência homérica ou anglo-saxônica. Saltavam aos olhos, portanto, heróis desengonçados, bufões e ingênuos, em posição similar à de Pepe legal (1958), e saturados de referências intertextuais: eram proprietários de um ferro-velho, em alusão às aventuras do homem de $a c ̧ o$; submetiam-se aos comandos do inspetor 000, paródia do agente 007, e detinham poderes na mesma linha da série Mulher biônica (1976). Conseguiam manter, contudo, a aspecto bufão e histriônico da série original (Os três patetas), ainda que as situações hilárias fossem adequadas ao universo futurista e às aspirações da criança do final da década de 1970, familiarizada a títulos como Guerra nas estrelas (1977). 
Fato não muito diferente pode ser apurado na série Os caça-fantasmas ${ }^{5}$, de 1986, inspirada no filme homônimo de 1984. No que tange especificamente ao filme, destacava-se um trio de cientistas tão desastrados quanto Os três patetas, formado por Peter Venkman, Egon Spengler e Ray Stantz, incumbidos de salvar a cidade de Nova Iorque de uma ameaça provocada por criaturas sobrenaturais. Para tanto, eram aclamados pela população como a derradeira esperança de preservar a nação norte-americana do quadro apocalíptico instalado. O sucesso do filme, por sua vez, rendeu a projeção de uma série animada bastante popular, que vigorou de 1986 a 1991. Tanto no clássico do cinema quanto na série animada, o universo de terror, que deveria sustentar o enredo, era desconstruído, questionado, desestabilizado e relativizado pelas personagens, abrindo espaço para que o humor conseguisse se sobrepor. Com efeito, o gigantesco monstro de marshmallow não assustava o destinatário, já que lembrava um brinquedo de infância; o fantasma Geleia mostrava-se extremamente caricato e faceiro, e as criaturas endiabradas perseguidas pelos heróis exibiam-se coloridas, radiantes e engraçadas. Em outra posição, mulheres e negros ainda atuavam na retaguarda: prova disso era Janine, contratada como secretária do grupo, enquanto Winston Zeddmore, o quarto caça-fantasmas, afrodescendente e último a integrar a equipe, colocava-se como o único que não tinha formação acadêmica. Além disso, a simplificação do enredo constitui outro traço marcante, tendo em vista que a série parece mais empenhada em narrar o cotidiano dos heróis, como pequenas “crônicas", perdendo seu aspecto, por vezes épico, que predominava no filme original.

Rambo (1986), não obstante, igualmente transitaria da sétima arte para as animações. O herói, dos estúdios Ruby Spears, integraria um grupo especial de agentes norte-americanos empenhados na luta contra as organizações terroristas. Morelli (2010), perante tal desenho, assevera que "a série durou apenas uma temporada e recebeu duras críticas da imprensa, por adaptar um personagem tão violento para um desenho animado" (p. 114). A rigor, Rambo, mesmo estando em um contexto histórico que pouco priorizava a ideologia ufanista (se comparado às séries animadas da década de 1960), apresentaria uma retórica ainda bastante nacionalista e conservadora, exaltando a própria pátria e sublinhando a superioridade e a supremacia dos Estados Unidos da América frente a outras nações. Na verdade, a personagem apareceu, pela primeira vez, em 1972, como protagonista do romance de David Morell, ganhando hipervalorização no conjunto de filmes que dosavam aventura, espionagem e guerra. Assim, Rambo, tanto na franquia de filmes quanto na série animada, trazia para o cotidiano

\footnotetext{
${ }^{5}$ A Disney, em 1837, lançou um curta-metragem que também mesclava humor e ambientes sombrios. Intitulado Fantasmas solitários, inseria Mickey, Donald e Pateta na condição de sobressaltados caçadores de criaturas assustadoras.
} 
infantil pesados armamentos como granadas, bombas, rifles, mísseis e metralhadoras. Não estava em cogitação a presença de martelos mágicos, espadas imponentes ou sabres de luz, como sugeriam outras produções da época. A indústria de brinquedos, inclusive, comercializava bonecos em miniatura do herói, acompanhados de réplicas de suas respectivas armas.

Robocop (1987), não destoando desse quadro, enviesava por um enredo tão violento quanto Rambo. Ambientado em um futuro não datado, na cidade de Detroit, narrava a trajetória do policial Alex Murphy, assassinado e, mais tarde, revivido como um ciborgue na forma do inexpressivo Robocop. A proposta retomava o plot do romance Frankenstein (1818), de Mary Shelley, uma vez que devolvia vida aos restos mortais de um homem, tornando-o, na condição de máquina, tão brutal quanto os criminosos que outrora o alvejaram. Em meio a sonhos e devaneios, alguns lampejos de sua vida antes da tragédia acabavam perseguindo-o. Como Batman, ele se mostrará atordoado e também buscará desforra.

Diante das críticas que se abateram sobre Rambo, os armamentos na animação de Robocop, veiculada pela Marvel, passaram a ser substituídos por pistolas a laser. Morellli chama a atenção para o fato de que a série, em posição similar ao filme, contemplava temas antes restritos ao mundo adulto e dificilmente abordados em uma animação, como o preconceito racial, a exclusão no ambiente de trabalho e a espionagem industrial. Outro tópico que merece realce é a construção, por parte da Marvel, de um herói taciturno, introspectivo e atormentado, tal qual Batman, o homem morcego, ou Wolverine, da série $X$-Man. Nos três desenhos, opta-se pelo uso intencional de cores escuras, sombrias, com destaque para o preto e as múltiplas variações do violeta, material semiótico que atestava o caráter distópico, macabro e obscuro das grandes metrópoles, especialmente no futuro incerto e desolado.

Composição bem diferente pode ser visualizada em O Máskara (1995), resgatando o nonsense e a ludicidade das animações anteriores a 1980, como o já mencionado grupo Robobos. Convém sublinhar a longa trajetória do herói histriônico - O Máskara - antes de protagonizar uma série animada, considerando que, em princípio, ele integrava uma revista em quadrinhos e apenas mais tarde acabou sendo recriado para o cinema. Foi o sucesso na grande tela que proporcionou a adaptação pelo estúdio Film Ramon, favorecendo um desenho que incursionava pelo traço realista e sua posterior estilização. No enredo, o retraído bancário Stanley Ipkis - à moda de Clark Kent ${ }^{6}$ - envolvia-se em situações estranhas e absurdas ao vestir uma máscara rústica, de povos antigos e revestida de mistérios. A máscara tinha o poder de

\footnotetext{
${ }^{6}$ Tanto em Clark Kent quanto em Stanley Ipkis revelavam-se homens reservados, inseguros e portadores de uma identidade secreta.
} 
libertar seus desejos reprimidos, tendo em vista que seu corpo era tomado e dominado por um ser irônico, pleno de elasticidade, que remetia às figuras cômicas e desarvoradas da Warner e da Hanna-Barbera. Promovendo a dessacralização dos heróis tradicionais, e em especial do homem de aço - a personagem Máskara não assumia nenhum discurso de protetor ou de combate à criminalidade, e tampouco revelava uma lição de moral no desfecho de cada episódio. Surgia sempre alegre, jocoso, cheio de truques. Criava situações inverossímeis em que, por intermédio da fantasia, brincava com trocadilhos da fala coloquial e tornava tangível o caráter conotativo das figuras de linguagem. Operava, muitas vezes, com o sorriso dissimulado, o visual exagerado e o astral elevado - na mesma proporção do Coringa, da série Batman e Robin (1968), embora despido de seus aspectos psicóticos. O amarelo que ecoava em suas indumentárias, na condição simbólica de signo em terceiridade (SANTAELLA, 1983), reportava à expressão de sucesso e de bem-aventurança. De acordo com Lurker (2003), o amarelo pode ser também analisado como a cor dos marginais, identificando, na Idade Média, os proscritos, as prostitutas, as meretrizes, os traidores e os hereges.

Para Denis (2010), o novo herói em que Stanley Ipkis se transformava dava continuidade à sua afeição pela animação clássica e pela magia hollywoodiana. Assim, os aspectos pós-modernos presentes na narrativa - tanto no filme de 1994 quanto em sua posterior animação - apontavam claramente para as referências e alusões à história do desenho animado e do cinema norte-americano. Ipskis praticamente se transformava em uma personagem de animação por se tratar de um leitor incorrigível e inveterado das histórias de Pernalonga, Patolino e Tom e Jerry.

Importa ainda asseverar, entre os títulos elencados, a dificuldade de conceituá-los em uma categoria fixa, rígida e única. Robobos, por exemplo, comportava a ficção científica e o humor clownesco típico de Os três patetas. Com efeito, a produção Os caça-fantasmas insistia no terror comedido com base na comédia pastelão. Rambo misturava aventura, suspense e guerra em uma narrativa vertiginosa. Robocop lidava com futurismo, espionagem e drama. $O$ Máskara explorava os recursos da metalinguagem e do nonsense em um enredo que interagia com a narrativa policial e a literatura fantástica. Todos esses títulos constituíam-se, assim, como ficções híbridas que corroboravam e arrolavam heróis já consagrados pela sétima arte, conscientes do filão que representavam e atendendo às exigências do mercado em expansão. Insistiam, portanto, em personagens de larga popularidade, responsáveis por sucessos de bilheteria e imediato retorno financeiro. 


\section{Conclusão}

O encaminhamento do artigo apontou para algumas diretrizes bastante inovadoras no processo de desenvolvimento, consolidação e expansão do mercado cinematográfico, especialmente no que diz respeito, por volta de 1980, à poética que embasava o cinema de animação. Em meio à bravura de heróis cultuados pela indústria cultural, como He-Man, Lion, Hank, Thundarr, Rambo, Bravestarr, Robocop e Wolverine, nota-se, até então, pouco espaço para grupos que ganhariam notoriedade na história do desenho animado que se firmou após o ano 2000, como mulheres, crianças e negros em ascensão.

Apesar de integrarem minorias, as figuras femininas ainda insistiam em ecoar nos interstícios de um ou outro episódio. Malgrado desfrutasse da condição de coadjuvante, era a mulher quem guardava o Castelo de Grayskull, desafiava inimigos mutantes e, ainda, zelava pelo homem amado ou pelo irmão caçula. Tributárias de Hipólita e das demais amazonas, exemplos desse segmento poderiam ser facilmente reconhecidos nas imagens de Teela [Mestres do universo (1983)], Sheyla [Caverna do dragão (1983)], Cheetara [Thundercats (1985)] e Tempestade [X-Man (1992)]. Talvez She-Ra seja a única heroína que, de fato, tenha desempenhado o papel de grande protagonista de um seriado, mas ainda assim as personagens femininas na narrativa obedeciam à mesma estética (e padrão) das figuras masculinas inscritas em Mestres do universo. É como se tivessem sido gestadas e concebidas à luz dos modelos propagados por He-Man, Mentor e Esqueleto. Parece não existir uma natureza eminentemente feminina nas heroínas e nos roteiros, mas a construção de um olhar que revela, em larga escala, a visão masculina perante os fatos.

Quanto às crianças, é nítido como eram representadas de maneira diversificada na extensa filmografia que se estende entre 1980 e 2000. Diferente do que acontecia nos decênios anteriores, os novos desenhos conseguiam desfazer a relação autoritária e congênita, atrelada à retórica do adulto sobre a criança, como se esta fosse concebida como uma tábula rasa, uma folha em branco, um ser fragilizado e destituído de qualquer experiência (como sugere parte expressiva de desenhos veiculados até o final da década de 1970). Afinados a essa retórica de autoafirmação, os ciclos de heróis enalteciam meninos e meninas bastante intrépidos, que jamais demonstravam qualquer indício de fraqueza. Mas, ainda assim, portavam-se como crianças, ao demonstrar interesse por brincadeiras, jogos e chacotas. É o caso, a título de ilustração, do pequeno bárbaro Booby [Caverna do dragão (1983)] ou dos destemidos irmãos Willy Kit e Willy Kat [Thundercats (1985)]. 
Negros também não estavam em primeiro plano, manifestando-se em posições secundárias. Exemplo dessa afirmação pode ser constatado na atuação da personagem Winston Zeddmore, o quarto caça-fantasmas, que se colocava como o único do grupo que não tinha formação acadêmica. Em linhas gerais, eram ainda o eurocentrismo, o etnocentrismo e o androcentrismo que embasavam a série, o que explica a ausência de heróis latinos, orientais ou de outras etnias. Importante esse dado, pois algumas narrativas que surgiriam posteriormente apresentariam novos olhares com relação a esses segmentos.

Vale também observar os diversos ciclos que contribuíram para a projeção dos heróis apresentados, e os vínculos que os mantiveram interligados aos ancestrais presentes na mitologia grega e nas lendas medievais. Todas as séries citadas parecem retomar o mesmo perfil de herói, empregando fórmulas que conseguem sucesso imediato, mas se desgastam com o tempo. Abrem espaço, consequentemente, para o mercado de brinquedos, que, atento à criança como principal consumidora, investe em bonecos semelhantes às personagens da TV. Revelamse, assim, marcas importantes como Trol, Gulliver e, sobretudo, Estrela.

Em última análise, resta reiterar como as produções que circulavam no final do século XX dialogavam com perfis de heróis bastante tradicionais, filiados, em grande parte, aos protagonistas das epopeias e das Novelas de Cavalaria. A espada, nesse sentido, tornava-se elemento frequente nas narrativas mencionadas e acabava impondo-se como signo que reportava ao sentido de poder, batalhas, justiça e castigo (LURKER, 2003). Tal arma, na verdade, instalava-se como uma referência intertextual às figuras do guerreiro Beowulf e do rei Arthur, reaparecendo, no cinema, na condição de sabre de luz [Guerra nas estrelas (1977)]. Será com a espada que Lion convocará sua legião de felinos [Thundercats (1985)], Adam se transformará no homem mais forte do universo [Mestres do universo (1983)] e o hercúleo Thundarr [Thundar, o bárbaro (1980)] enfrentará seus adversários. A opção do cinema de animação por esse caminho e o sucesso conquistado ao longo de vinte anos devem-se, é claro, ao êxito que os roteiristas testemunharam com o advento de filmes que conquistaram o segmento juvenil e que, também, revisitavam os universos mitológicos da Antiguidade - como Jasão e os argonautas (1968), Fúria de titãs (1981) e Conan, o destruidor (1982), entre outros. Tais observações, contudo, não pretendem esgotar a presente temática, mas chamar a atenção do leitor para novas pesquisas que incorporem outras contribuições para o debate em torno dos modos de representação de heróis nas séries animadas. 


\section{Referências}

ALVES, M. R. Eneida: a evolução do herói. Revista conhecimento prático: literatura. São Paulo: Escala Educacional, 2010.

AUMONT, J; MARIE, M. Dicionário teórico e crítico de cinema. Campinas: Papirus, 2003.

BULFINCH, T. O livro de ouro da mitologia: histórias de deuses e heróis. São Paulo: Ediouro, 2006.

CAMPBELL, J. O herói de mil faces. São Paulo: Pensamento, 2007.

CAVALCANTI, C. Como entender a pintura moderna. Rio de Janeiro: Editora Rio, 1975.

COELHO, N. N. Literatura infantil: teoria, análise e didática. São Paulo: Moderna, 2000.

COELHO, N. N. Panorama histórico da literatura infantil/juvenil. São Paulo: Edições Quíron, 1989.

DENIS, S. O Cinema de animação. Lisboa: Edições Texto e Gráfica, 2010.

GOTLIB, M. G. Teoria do conto. São Paulo: Ática, 2000.

JAEGER, E. Paideia: a formação do homem grego. São Paulo: Martins Fontes, 1986.

LURKER, M. Dicionário de simbologia. São Paulo: Martins Fontes, 2003.

MORELLI, A. Super-heróis nos desenhos animados. São Paulo: Editora Europa, 2010.

SANTAELLA, L. O que é semiótica. São Paulo: Brasiliense, 1983.

SHELLEY, M. Frankenstein. São Paulo: Editora Oxford, 1989 (primeira edição em 1818).

SOUZA, R. J. Narrativas infantis: a literatura e a televisão de que as crianças gostam. Porto Alegre: PUC, 1992.

\section{Filmes}

As novas viagens de Simbad. Direção de Gordon Hessler. Columbia Pictures. Reino Unido: 1974. Fortaleza: Classicline, 2002. DVD (1h45m), colorido.

Blade runner, o caçador de androides. Direção de Ridley Scott. Produtora: The Ladd Company Shaw Brothers Blade Runner Partnership. Estados Unidos: 1982. São Paulo: Warner Bros, 1982. VHS (1h47 m), colorido.

Bravura indômita. Direção de Henry Hathaway. Hal Wallis. Estados Unidos: 1969. Rio de Janeiro: Paramount Pictures Brasil, 1969. VHS (2h 06m), colorido.

Conan, o destruidor. Direção de Richard Fleischer. Universal Pictures. Estados Unidos: 1982. São Paulo: Fox Film do Brasil, 1982. VHS (1h 41m), colorido.

Fúria de titãs. Direção de Dasmond Davis. Warner Bros. Reino Unido: 1981. São Paulo: Warner Bros, 2008. DVD (1h 58m), colorido. 
Guerra nas estrelas. Direção de George Lucas. Lucas Film. Estados Unidos: 1977. São Paulo: Fox Film, 1977. VHS (2h10 m), colorido.

Jasão e os argonautas. Direção de Don Jaffey. Morningside Productions. Inglaterra/ Estados Unidos: 1968. São Paulo: Columbia Pictures, 1968. VHS (1h 44m), colorido.

Jornada nas estrelas. Direção de Gene Roddenberry. Paramount. Estados Unidos, 1979. São Paulo: Paramount, 1979. VHS (2h10), colorido.

Mad Max. Direção de George Miler. Crossroads, Kennedy Muller: Austrália, 1979. São Paulo: Village Roadshow Pictures, 1979. VHS (1h28m), colorido.

Matar ou morrer. Direção de Fred Zinneman. Carl Foreman e Stanley Kramer: Estados Unidos, 1952. VHS (1h24m), preto e branco.

Mulher biônica. Direção de Kenneth Johnson MCA/Universal, Estados Unidos: 1976. Rio de Janeiro: NBC Universal, 1976. VHS (média 50m cada episódio), colorido.

No tempo das diligências. Direção de Walter Wanger e John Ford. Estados Unidos, 1939. VHS (1h36m), preto e branco.

O planeta dos macacos. Direção de Franklin J. Schaffner Legendary, Estados Unidos: 1969. São Paulo: Fox Film do Brasil, 1969. VHS (2h), colorido.

\section{Desenhos animados (longa-metragem) e séries animadas}

A tartaruga Touchê. Produção de Willian Hanna e Joseph Barbera. Estúdios Hanna-Barbera: Estados Unidos, 1962. https://www.youtube.com/watch?v=_5ryN-ShL8A (acesso em 21/09/2018).

Akira. Produção de Shunzo Kato, Yoshimasa Mizuo, Riohei Suzuki. Akira Company Ltd: Japão, 1988. São Paulo: Editora Globo e Rede Bandeirantes: 1991. VHS. (2h4 min), colorido.

As tartarugas ninja. Produção de Jack Mendelsohn. WolfSwenson, Studios e Playmates Stoy: Estados Unidos, 1987. https://www.youtube.com/watch?v=eJe6ad8n0aA (acesso em 18/08/2018).

Batman e Robin. Produção de Hal Sutherland. Estúdios Filamtion: Estados Unidos, 1968. https://www.youtube.com/watch?v=Ng0ohdyacTo (acesso em 21/09/2018)

Bravestarr. Produção de Bob Arkwright e Lou Zukor. Estúdios Filamtion: Estados Unidos, 1987. https://www.youtube.com/watch?v=nEnEHfVgN40 (acesso em 20/09/2018).

Caverna do dragão. Produção de Bob Richardson. TSR e Marvel: Estados Unidos, 1983. https://www.youtube.com/watch?v=zAeJ3_Wwt5Q (acesso em 21/09/2018).

Dinosaucers: o planeta dos dinossauros. Produção de Michael Uslan. DiC Entertainment: Estador Unidos,1987. https://www.youtube.com/watch? $\mathrm{v}=\mathrm{KmuLjXWlc24}$ (acesso em 21/09/2018).

Fantasmas solitários. Produção de Burt Gillett. Estúdios Disney: Estados Unidos, 1937. https://www.dailymotion.com/video/x2tkp9e (acesso em 21/09/2018). 
Galaxy rangers. Produção de Robert Mandell. Gaylord Productions: Estados Unidos, 1986. https://www.youtube.com/watch?v=zvePRGJxYrg (acesso em 20/09/2018).

He-Man e os mestres do universo. Produção de Hal Sutherland. Estúdios Filamtion: Estados Unidos, 1983. São Paulo: Focus Filmes, 2012.

O Cavaleiro solitário. Produção de Bob Arkwright e Lou Zukor. Estúdios Filamtion: Estados Unidos, 1980. https://www.youtube.com/watch?v=960aO5HaQlk (acesso em 22/09/2018).

O Máskara. Produção de John Arcudi, Doug Mahnke e Mike Richardson. Estúdios Film Roman: Estados Unidos, 1995. https://www.youtube.com/watch?v=69pPbrTINmc (acesso em 01/09/2018).

O poderoso Mighton. Produção de Alex Toth. Estúdios Hanna-Barbera: Estados Unidos, 1967. https://www.dailymotion.com/video/x1tzn0x (acesso em 01/09/2018).

Os caça-fantasmas. Produzido pela Sony Pictures Television e DiC Entertainment. Columbia Pictures: Estados Unidos, 1986. https://www.youtube.com/watch?v=G7J2ZMrhWco (acesso em 02/09/2018).

Os Herculoides. Produção de Willian Hanna e Joseph Barbera. Estúdios Hanna-Barbera: Estados Unidos, 1966. https://www.youtube.com/watch?v=I82hz8VrsH0 (acesso em 02/09/2018).

Pac Man. Produção de Willian Hanna e Joseph Barbera. Estúdios Hanna-Barbera: Estados Unidos, 1984. https://www.youtube.com/watch?v=QojutCuuH3w (acesso em 05/08/2018)

Pepe legal. Produção de Willian Hanna e Joseph Barbera. Estúdios Hanna-Barbera: Estados Unidos, 1958. https://www.dailymotion.com/video/xycl91 (acesso em 08/08/2018).

Rambo. Produção de Roby Spears Enterprises. Universal Studios: Estados Unidos, 1986. https://www.youtube.com/watch?v=t6RP2AlswEc (acesso em 22/09/2018).

Robobos. Produção de Willian Hanna e Joseph Barbera. Estúdios Hanna-Barbera: Estados Unidos, 1978. https://www.dailymotion.com/video/x17u2th (acesso em 17/08/2018).

Robocop. Produção dos Estúdios Marvel. Orion Films: Estados Unidos, 1987. https://www.youtube.com/watch?v=CvRcXw_XuZE (acesso em 10/09/2018).

She-Ra. Produção de Hal Sutherland. Estúdios Filamtion: Estados Unidos, 1985. São Paulo: Focus Film, 2012.

Space Ghost. Produção de Willian Hanna e Joseph Barbera. Estúdios Hanna-Barbera: Estados Unidos, 1966. https://www.youtube.com/watch?v=A5K8E48NAOk (acesso em 16/09/2018).

Super Mário Brothers. Produção de Andy Heyward e John Grusd. DiC Entertainment: Estados Unidos, 1989. https://www.youtube.com/watch?v=UBN3C2KH3bs (acesso em 07/09/2018).

Superman. Produção de Fleiscer Studios e Famous Studios: Estados Unidos, 1941. https://www.youtube.com/watch?v=djwgODXqIro (acesso em 12/09/2018). 
Thundarr, o barbado. Direção de Jerry Eisenberg. Estúdios Roby Spears: Estados Unidos, 1980. https://www.youtube.com/watch?v=rfT5qRNjFJg (acesso em 15/09/2018).

Thundercats. Produzido por Arthur Rankin Jr. e Jules Bass. Estúdios Rankin e Bass: Estados Unidos, 1985. https://www.youtube.com/watch?v=L6f3J3PE7mM (22/09/2018).

Visionários: os cavaleiros da luz mágica. Produção dos Estúdios Sunbow e TMS: Estados Unidos, 1987. https://www.youtube.com/watch?v=QZMtCawBxUI (acesso em 22/09/2018).

X-Men. Produção dos Estúdios Marvel: Estados Unidos, 1992.

https://www.dailymotion.com/video/x600jh1 (acesso em 09/09/2018).

Zorro. Produção de Don Christensen. Estúdios Filamtion: Estados Unidos, 1981. https://www.youtube.com/watch?v=RkiWK99I5bQ\&list=PLXiLw1i6a9wu1SWUE4BOqBm wyWcQDRUBg (acesso em 19/09/2018).

Recebido em 22/12/2018

Aceito para publicação em 16/04/2019 